\title{
Relating the Ancient Ona Culture to the Wider Northern Horn: Discerning Patterns and Problems in the Archaeology of the First Millennium BC
}

\author{
Matthew C. Curtis
}

Published online: 23 January 2010

(C) The Author(s) 2010. This article is published with open access at Springerlink.com

\begin{abstract}
Archaeological research carried out between 1998 and 2003 on the Asmara Plateau of Eritrea has provided new insights concerning the development of early-to-mid first millennium BC settled agropastoral communities in the northern Horn of Africa. The settlement, subsistence, and material culture of these communities in the greater Asmara area, referred to as the "Ancient Ona culture," bear both unique qualities and striking similarities to coeval communities in Tigray, Ethiopia. This article provides an overview of regional settlement data and ceramic and lithic traditions from the greater Asmara area, drawing comparisons to other contexts of this period in the archaeology of the wider northern Horn. It is argued that we can see among the Ancient Ona sites distinct localized cultural expressions and development as well as strong links to a wider first millennium BC macrocultural identity.
\end{abstract}

Résumé Des recherches archéologiques conduites entre 1998 et 2003 dans le plateau d'Asmara en Érythrée ont produit des nouvelles informations sur le développement des communautés agro-pastorales dans la première moitié du premier millenaire av. J.-C. dans la Corne de l'Afrique. Le mode d'occupation du territoire, les moyens de subsistance, et la culture matérielle des communautés de la région d'Asmara - que l'on appelle 'culture Ona ancienne' - ressemblent, malgré leurs particularités, aux communautés vivant à la même époque dans le Tigray (Ethiopie). Cet article présente une revue des données sur l'occupation de l'espace au niveau régional et des traditions lithiques et céramiques de la région d'Asmara, qui sont comparées à lumière d'autres contextes archéologiques de la Corne de l'Afrique datant de la même période. On suggère que les sites de la culture Ona

\footnotetext{
M. C. Curtis $(\bowtie)$

Department of Anthropology, University of California, Santa Barbara,

2001 Humanities and Social Sciences Building, Santa Barbara, CA 93106-3210, USA

e-mail: matthew-curtis@sbcglobal.net
} 
ancienne présentent des expressions culturelles et développements très localisés ainsi que de fortes attaches à une identité macro-culturelle en vigueur à de plus vastes échelles durant le premier millenaire av. J.-C.

Keywords Eritrea $\cdot$ Ethiopia $\cdot$ Northern Horn of Africa $\cdot$ First millennium BC . Ancient Ona · Pre-Aksumite · Asmara · Archaeology $\cdot$ Lithics $\cdot$ Ceramics ·

Settlement patterns $\cdot$ Regional survey

\section{Introduction}

Research in the greater Asmara area of Eritrea carried out by American and Eritrean archaeologists between 1998 and 2003 concentrated on regional survey, site mapping, and small, strategic test excavations identifying the presence of substantial first millennium BC occupation of the Asmara Plateau by an archaeological "culture group" termed the Ancient Ona (Schmidt et al. 2008a). This research revealed settlement patterning and relationships between the ancient built and natural environments, documented domestic architectural details and household features, created basic artifact typologies, tied sites' surface material culture to excavated contexts, and obtained a variety of subsistence data and chronometric samples. The focus here is on relating key components of this research to the wider archaeology of the highlands in the northern Horn of Africa, particularly the Aksum, Yeha, and Gulo-Makeda areas of Tigray, Ethiopia (Fig. 1). Discussion of central attributes of Ancient Ona material culture and settlement patterning is followed by a brief

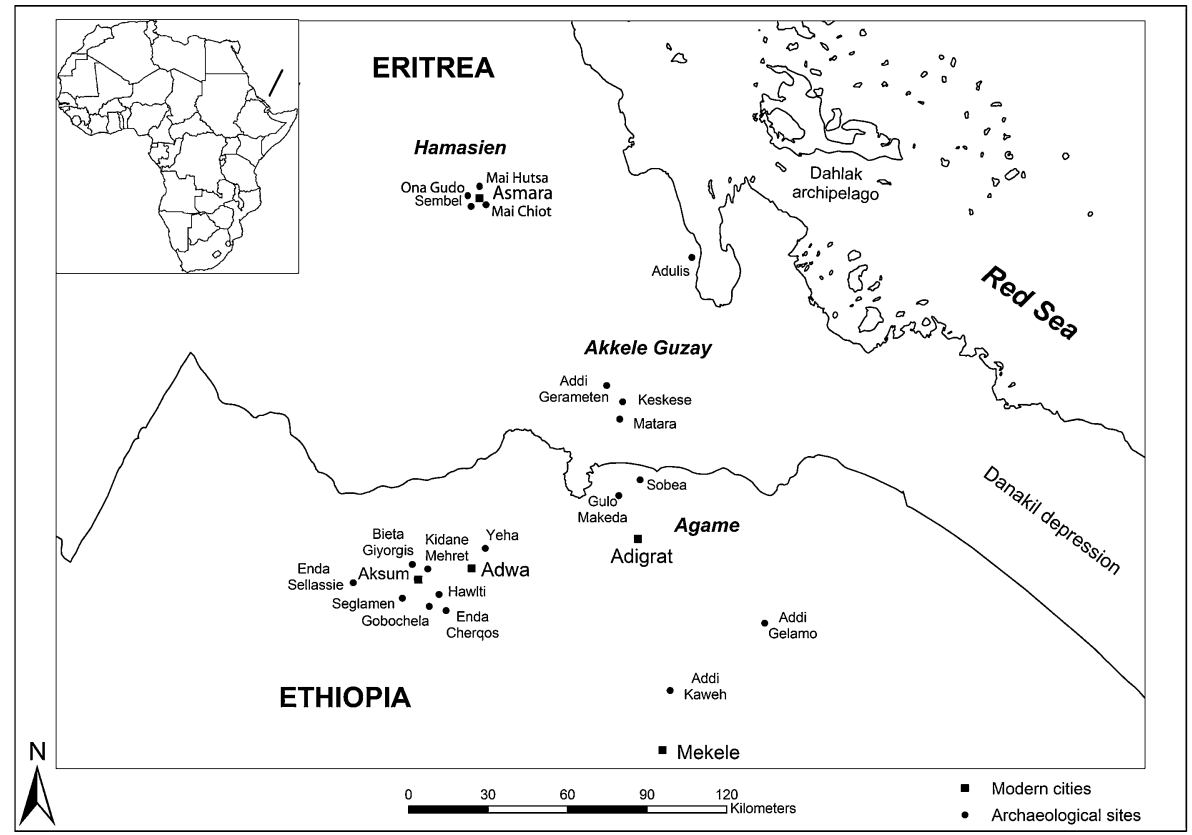

Fig. 1 Map of the northern Horn showing principal sites discussed in this issue (Luisa Sernicola) 
comparison with material represented in first millennium BC contexts from Tigray. It is proposed that we can see among the Ancient Ona sites distinct localized cultural expressions and development as well as strong links to a wider first millennium BC macro-cultural identity of the northern Horn.

\section{Background to the Study}

The early to mid-first millennium BC in the highlands of the northern Horn witnessed the growth of demographic complexity, diverse agropastoral economies, and the appearance of social differentiation. On the highland landscapes, from the Aksum area of Tigray to the Asmara Plateau of the Hamasien region of Eritrea, settlements ranged from dispersed homesteads and hamlets to nucleated villages and towns built of stone; their inhabitants herded domesticated cattle, goats and sheep, and cultivated cereals and other crops such as barley, wheat, linseed, and, at least in the Asmara area, lentil and the African grain tef (Boardman 1999, 2000; Boardman and Phillipson 2000; D. W. Phillipson 2000; Cain 2000; D'Andrea et al. 2008b; Shoshani et al. 2008). In addition, also occasionally appearing across parts of this landscape were specialized ceremonial or ritual centers containing distinctive and elaborate monumental architecture, complex tombs, dedicatory inscriptions, and ceremonial objects. Archaeologists working in the northern Horn have long defined first millennium BC "Pre-Aksumite" communities in relation to elements contained in these ceremonial centers, often referring to the culture as "Ethio-Sabaean" (Anfray 1968; de Contenson 1981; Fattovich 1990). Formal inscriptions in Epigraphic South Arabian script containing the names of rulers, references to lineage or clan groups, and a cosmology with a number of deities also occurring in South Arabia have long been characterized as hallmarks of this "Ethio-Sabaean" identity. Other types of material culture deemed to be central features of this identity include copper alloy openwork badges or monograms and ceremonial objects including votive altars, incense burners, and stone and ceramic sculptural forms with presumed South Arabian prototypes. However, as argued elsewhere (Curtis 2004, 2005, 2008; Fattovich 2009; Manzo 2009; D. W. Phillipson 2000), although such symbols traceable to South Arabian prototypes have been used as defining features, they can be documented in only a relatively small range of "Pre-Aksumite" elite and ceremonial contexts in Tigray and Akele Guzay.

The greater Asmara area of Eritrea, located in the northern portion of the presumed "Pre-Aksumite" culture area, while possessing demographic complexity with widespread evidence of some of the earliest permanently settled villages and small towns, lacks a number of the elements that have been deemed characteristic of "Ethio-Sabaean" culture. Intensive regional survey and test excavations have not produced evidence of monumental architecture and inscriptions or the range of ceremonial objects with South Arabian-like features such as those found at Yeha and Hawlti in Tigray. A similar situation exists for the first millennium BC occupation of the D site of Kidane Mehret in the Aksum area (D. W. Phillipson 2000) and for large "Pre-Aksumite" settlements recently documented by the Gulo-Makeda Archaeological Project in eastern Tigray (D'Andrea et al. 2008a). Like the Ancient Ona sites of the Greater Asmara area, the Kidane Mehret and Gulo-Makeda sites challenge the 
notion of a widespread "Ethio-Sabaean" identity and suggest a more complex picture of regional and local archaeological culture areas.

Archaeological survey of $90 \mathrm{~km}^{2}$ in a $170-\mathrm{km}^{2}$ survey universe on the Asmara Plateau between 1999 and 2003 (Curtis and Schmidt 2008) documented 304 archaeological sites ranging from less than $50 \mathrm{~m}^{2}$ to over 20 ha in size and representing a range of occupation periods from at least the early Holocene to the twentieth century AD (Figs. 8 and 9). Detailed site mapping, systematic surface collections, recording of on- and off-site physiographic survey data, and test excavations at ten sites have shown that while many of the documented areas provide evidence of multi-component use and multi-period occupation, by far the dominant archaeological cultural expression in the greater Asmara area was that of what we have come to call the Ancient Ona culture of the first millennium BC (Figs. 2 and 9). In fact, more than $90 \%$ of sites documented in the survey contained Ancient Ona material on their surfaces.

Test excavations show that village sites in the greater Asmara area were occupied for at least 400 years. Given the presence of archaeobotanical and faunal remains from hearths and other occupation features of the earliest levels at several Ancient Ona villages, these sites seem to have been first settled by people who either already had in place an established and fully functioning agropastoral tradition or developed such a system in situ with great rapidity. While there is significant variation in subsistence strategies and lithic raw materials utilized in diverse zones of the Asmara Plateau during the first millennium BC (see Teka and Okubatsion 2008; Curtis and Schmidt 2008; Schmidt et al. 2008b; Schmidt 2009), there is general continuity in subsistence practices and in material culture between communities and through time. By the beginning of the fourth century $\mathrm{BC}$, there seems to have been a major period of change in settlement and community composition with the abandonment of villages and small towns that had been occupied for about 400 years, possible

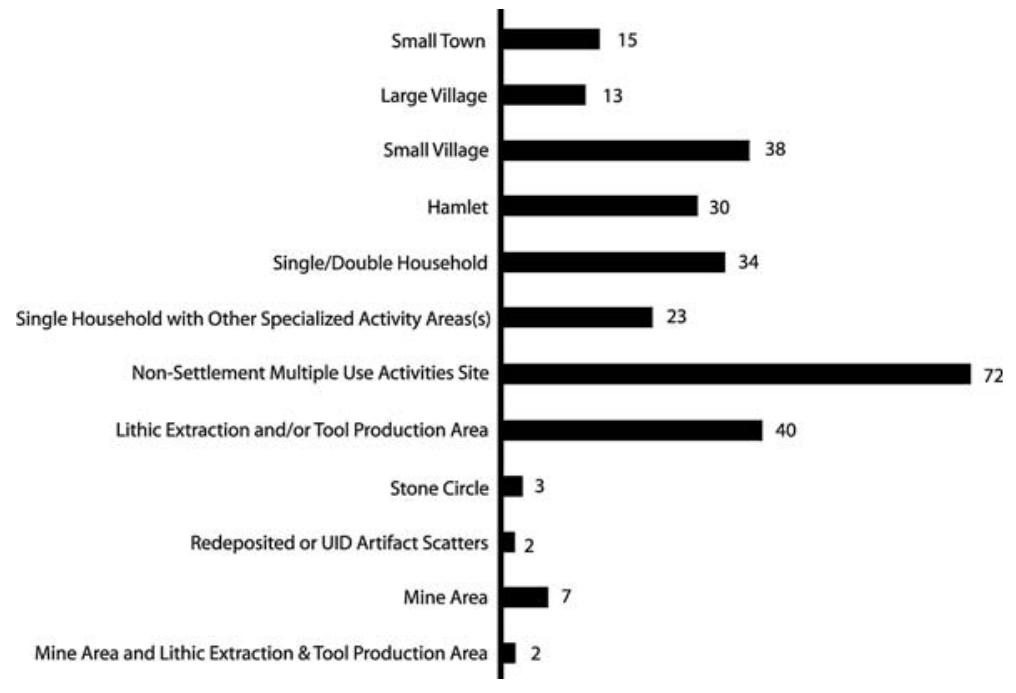

Fig. 2 Number of first millennium BC sites that were documented and mapped in the Greater Asmara survey area between 1998 and 2003 by general type. Both settlement and non-settlement site types are represented 
changes in subsistence patterns, the disappearance of bulls' heads figurines, the appearance of new forms of elite identity such as seen in the burial at Mai Temenai (Libseqal 2005), and the incorporation of copper alloy metalwork including at least one example of a presumed monogram similar to those recognized in Tigray and Akele Guzay (Schmidt et al. 2008a: 142, Fig. 6.42).

\section{Regional Settlement}

The greater Asmara area comprises the central and eastern portions of the Asmara Plateau, a relatively flat peneplain ranging from approximately 2,200-2,500 $\mathrm{m}$ above sea level, containing broad swales and shallow stream valleys and basins, gentle ridges, occasional springs, and punctuated by small flat-topped hills or ambas. The Asmara Plateau has fertile luvisols and vertisols, receives 500-700 mm of rainfall annually, and possesses gold deposits and copper mineralization. The first millennium BC agropastoral communities of the Asmara Plateau lived at a relatively high population density in settlements of varying size from scattered homesteads to villages and small towns. Also found across the survey area were multipurpose use and work-station areas where ceramic material and lithics were present but where there was little evidence for mounds or other architectural features. Archaeological survey documented 279 sites containing discernible first millennium BC material culture and comprising a number of likely settlement and multiple-use site types, including small towns, large villages, small villages, hamlets, isolated individual households, lithic extraction and tool production areas, stone circles, mine areas, and multiple-use activity areas including stock enclosures, agricultural threshing and rest areas, ash dumps, and possible communal ritual areas (Figs. 2 and 8). Seventy-one percent of these sites showed surface evidence of first millennium BC activity only, while $29 \%$ revealed evidence for multi-component occupation, including material attributable to other periods in addition to the first millennium BC. In the $90 \mathrm{~km}^{2}$ intensively surveyed for sites with significant evidence of first millennium BC material, an average of three sites per square kilometer were identified, with an average area of 1.2 ha. If we extrapolate to the entire survey universe, we might expect to find approximately 500 sites dating to this period in the greater Asmara area.

Of the 15 small-town-sized settlements with first millennium BC occupations, only six sites are over 7 ha in size (Figs. 3 and 9). Of the four sites that cover more than 9 ha, three (Sembel, Sembel Kushet, and Mai Hutsa) show evidence of having been both residential and ritual centers (Fig. 8; see Schmidt 2009). The ratio of the smallest four settlement types designated for the greater Asmara area (single households with other activities, single/double households, hamlets, and small villages) and the two largest units of first millennium BC settlement (large villages and towns) is 4.5:1. Non-settlement areas, particularly those with evidence of multiple artifact types, were well represented in the survey area. Such areas were often located in rocky outcrops above or adjacent to cultivated fields.

Eight of the 15 small town settlements were within $250 \mathrm{~m}$ of streams that today are perennial water sources, having either moving water or large pools year-round. All of the small towns were located within $500 \mathrm{~m}$ of major seasonal or perennial 
Fig. 3 Ancient Ona first millennium $\mathrm{BC}$ settlement site rank/size distribution

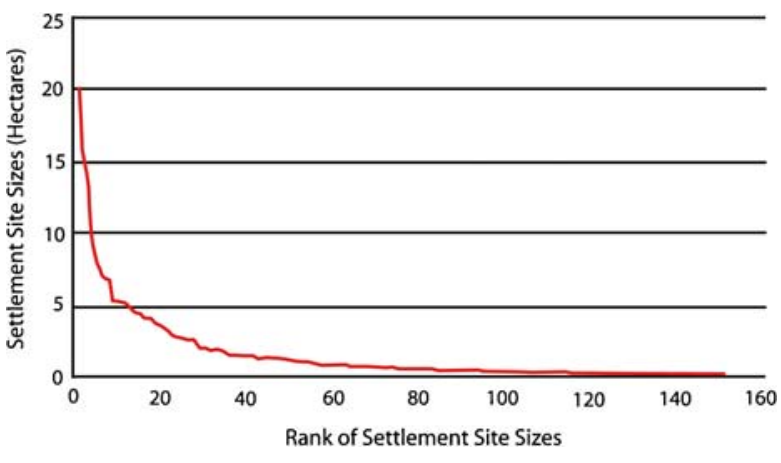

streams (Figs. 8 and 9), with most located on slight rocky ridges overlooking cultivated fields and seasonal and/or perennial water courses. Access to water and preserving the lower lying fertile swales and shallow valley bottoms for agricultural uses seem to have been determinant in locating the larger ancient settlements, mirroring the present pattern of modern villages that sit on ridges above fertile fields (see Curtis 2005).

There were several localities where prominent ancient stone-built towns and/or several large villages in close proximity were surrounded by small villages, hamlets, and homesteads. However, this pattern does not hold across the whole survey area. For example, in places adjacent to the central agricultural basin immediately north and south of the central portion of the Mai Bela stream, the largest watercourse in the survey area, there was wide spacing of village and hamlet communities and the integration of large multiple-use spaces (Figs. 8 and 9). And in the more topographically complex, hilly northern area of the Asmara Plateau, villages, hamlets, and household units were densely distributed and exhibit diversity in settlement size and type. Environmental and survey data, indicating the presence of large open spaces between settlements, suggest that maintenance of the commons may have been a central feature of Ancient Ona settlement (Curtis and Schmidt 2008).

The relatively flat and fertile plains in the central portion of the Asmara Plateau between the Sembel and Mai Bela streams appear largely devoid of archaeological sites (Fig. 9). This area, with its rich soils and perennial watercourses, was likely the heart of Ancient Ona agriculture on the Asmara Plateau. These fields and associated occasional rock outcrop areas seem to have been the focus of a range of agropastoral activities by people from the various hamlets, villages, and small towns lying on the margins of this central zone. The complete absence of perimeter walls or other evidence of ancient fortification, the dearth of elite centers and prestige goods, and generally non-nucleated settlement patterns suggest the growth of communities along non-hierarchical patterns with a commitment to preserving common space and open public ritual space (see Schmidt 2009). Such observations tentatively indicate aspects of an egalitarian Ancient Ona social order for much of the first millennium BC. While we see that several large settlements occupy a substantial presence on the Asmara Plateau (Fig. 3), we are unable to observe their dominance over other communities in the region. Sites such as Sembel, Sembel Kushet, and Mai Hutsa (Fig. 8) may have been significant residential centers and the loci of large community ritual activities, as demonstrated by denser and more varied domestic 
architectural remains and by the dense distribution of bulls' heads figurines and ashy deposits (Curtis and Schmidt 2008; Schmidt et al. 2008b; Schmidt 2009), but thus far we are unable to observe evidence that such sites functioned as administrative centers. And while social differentiation may be apparent at the end of the Ancient Ona culture occupation of the Asmara Plateau, as the late fifth- to early fourthcentury BC Mai Temenai burial suggests (Libseqal 2005), there is yet little other evidence of a widespread sociopolitical hierarchy or centralization of power by elites during this period in the greater Asmara region.

Some general contrasts and comparisons may be made with available data from other areas of the northern Horn, particularly the regional survey directed by Michels $(1979,1994,2005)$ in 1974 over $201 \mathrm{~km}^{2}$ of a 714-km² study area between Aksum and Yeha, and the preliminary findings of a recent archaeological survey in a $100-\mathrm{km}^{2}$ section of the Gulo-Makeda area in eastern Tigray (D'Andrea et al. 2008a).

A total of 267 period-specific archaeological sites were documented in the AksumYeha survey region using a stratified random sample, producing 1.3 sites per square kilometer (Michels 2005). However, only 35 sites dating, by obsidian hydration, between 700 and $400 \mathrm{BC}$ were located, revealing an early to mid-first millennium $\mathrm{BC}$ settlement density of less than 0.2 sites per square kilometer. Michels saw little evidence for an "Early Pre-Aksumite" site hierarchy in the Aksum-Yeha area. He saw no indication that the large villages functioned as central places politically or economically, and smaller communities did not cluster in satellite fashion around the larger settlements (Michels 2005: 63-64). Most of the "Pre-Aksumite" settlements documented were situated along principal drainage areas and in close proximity to rich soils. However, outside of this, Michels perceived non-uniform community patterning for his "Early Pre-Aksumite" period with three general trends apparent: (1) many small settlements scattered widely; (2) isolated small settlements located in otherwise unpopulated areas; and (3) a nucleation of a sub-regional population in one town-sized settlement in the Yeha Valley (Michels 2005: 64).

Thus, despite the much lower population density of early to mid-first millennium $\mathrm{BC}$ settlement in the Aksum-Yeha area, there are important general similarities with the greater Asmara area in landscape use and settlement patterning. While there are such general similarities in regional settlement size and distribution, the AksumYeha area of the early to mid-first millennium BC does differ from the Asmara Plateau in the presence of monumental architecture, inscriptions, and, at the site of Yeha, a probable elite cemetery. Although an elite burial dating to the terminus of the Ancient Ona culture has been documented on the Asmara Plateau (Libseqal 2005) and one presumed elite copper alloy monogram or "identity badge" has been recovered from a first millennium BC context (Schmidt et al. 2008b), we have yet to find an Ancient Ona culture-site area with elite material culture or monumental architecture, comparable to that apparent at the Great Temple and Grat Be'al Gebri complex at Yeha (Anfray 1972a, b, 1973, 1997; Fattovich 1972a, b, 2009; Manzo 2009; Robin and de Maigret 1998). While monumental architecture and epigraphic South Arabian inscriptions are apparent in Eritrea at sites such as Keskese (Fig. 1) in the Akele Guzay area nearly $100 \mathrm{~km}$ south of the Asmara Plateau (Curtis and Habtemichael 2008), the paucity of such features of elite identity on the Asmara Plateau itself, despite a comparably dense and permanently settled population, remains an intriguing phenomenon that holds great significance for our understand- 
ing of sociopolitical complexity across the northern Horn in the first millennium BC (see Curtis 2004, 2005, 2008).

In eastern Tigray, the Gulo-Makeda Archaeological Project survey work in 20052006 identified 71 sites using both random and judgmental sampling techniques (D'Andrea et al. 2008a). In areas systematically surveyed, there is a density of 6.7 sites of all periods per square kilometer. Of the 71 sites documented, at least 21 have "Pre-Aksumite" material culture. Thirteen of these are reported to be settlements dating to the "Pre-Akumite" period and ranging in size from $<1$ to more than 22 ha (D'Andrea et al. 2008a: 158). Seven of these "Pre-Akumite" settlement sites fit within the small-town category employed for the greater Asmara area ( $>4 \mathrm{ha}$ ). Utilizing digital elevation model data and GIS tools, the authors argue that larger settlements were located, in part, on the basis of water availability in moderate to high flow-potential areas (D'Andrea et al. 2008a: 158). Landform analysis conducted for the Gulo-Makeda survey area suggests that a significant number of sites are located on sediment slopes, perhaps "to avoid occupation of valley bottoms with valuable arable land and grazing areas" (D'Andrea et al. 2008a: 160). As in the Asmara area, there are ethnographic correlates for such settlement patterning in eastern Tigray (e.g., Lyons 2007). Tentative research results from Gulo-Makeda suggest a higher density of first millennium BC settlement than that of the AksumYeha area, with site types and distributions more comparable to the Greater Asmara area.

\section{Lithics and Ceramics}

In the following discussion, general characteristics of Ancient Ona ceramic and lithic material culture are presented, with particular examples drawn from material excavated in 1999-2000 from two sites on the Asmara Plateau, Mai Hutsa and Ona Gudo (Fig. 8). Both represent small towns, yet they differ from one another in environment: Mai Hutsa is located in the rocky and hilly northeastern portion of the Asmara Plateau adjacent to the eastern escarpment, while Ona Gudo sits above the Mai Bela stream valley adjacent to the heart of the plateau's fertile basin. Comparative analysis of faunal and paleoethnobotanical data suggests subtle but important differences in subsistence practices between the two site areas (D'Andrea et al. 2008b; Schmidt 2009), perhaps related to differences in environmental setting and access to resources. In addition to the Mai Hutsa and Ona Gudo test excavations, general lithic and ceramic data from the 1999-2000 survey (Curtis 2005) and from excavations at Sembel, Mai Chiot, and Weki Duba (Schmidt et al. 2008a) are considered here. The 1999-2000 research, which formed the initial phase of the larger survey project conducted on the Asmara Plateau subsequently, included systematic surface collections from 80 archaeological sites $(26 \%$ of all sites documented on the Asmara Plateau) in fifteen $1-\mathrm{km}^{2}$ survey units and the collection of environmental data in 1,500 squares measuring $10,000 \mathrm{~m}^{2}$ each. After mapping, each of the 80 sites received an artifact surface collection comprising $1 \%$ of the total area via a random sampling procedure (Curtis 2005). Material culture from these collections substantiates regional perspectives drawn from excavated contexts. Finally, in the discussion below, data from the greater Asmara area surveys 
and excavations are examined in relation to wider general descriptions of material culture from sites of the first millennium BC in Tigray.

The Mai Hutsa site exceeded 15 ha in size and contains a central mound feature measuring more than 1 ha in area, exhibiting at least 16 linear stone walls visible on the surface and rising nearly $4 \mathrm{~m}$ above the surrounding landscape. In 1999-2000, a $2 \times 3-m$ test excavation was made over two wall features at the top of the main mound and the deposit was excavated to sterile soil at a depth of $2.35 \mathrm{~m}$. The smaller Ona Gudo site, nearly 5 ha in size, was marked by a series of five terraces/platforms on which much eroding ash and several exposed ancient walls were found. In 2001, a $2 \times 2-m$ test excavation unit was made on the topmost platform near an exposed wall and ash deposit and excavated to sterile soil at $2.30 \mathrm{~m}$ below datum. Radiocarbon dates from stratified contexts (three from Mai Hutsa and four from Ona Gudo) suggest occupation between about 800 and 400 BC (Curtis 2005; Schmidt and Curtis 2001; Schmidt et al. 2008b). Like other test excavations in the survey area, the Mai Hutsa and Ona Gudo excavations produced abundant macrobotanical remains and faunal material indicating a repertoire of cereal and legume crops, cattle, and ovicaprines (Curtis 2005; D'Andrea et al. 2008b; Shoshani et al. 2008; Schmidt 2009), multiple hearth features, and a range of material culture types including stone beads, clay zoomorphic and stone bulls' heads figurines, quartz crystal, slate fragments, stone and ceramic lip and/or ear plugs, and heavy concentrations of ceramic sherds and lithic artifacts. Here, we will focus on the lithics and ceramic material from Mai Hutsa and Ona Gudo, with particular emphasis on formal chipped stone tool types and general ceramic vessel forms, ware types, and decorative motifs, drawing contrasts and comparisons with other first millennium $\mathrm{BC}$ excavated contexts in the greater Asmara area and in Tigray.

\section{Lithics}

Test excavations at Mai Hutsa and Ona Gudo produced a combined total of 8,612 chipped stone artifacts, including unmodified angular waste, weighing $42.0 \mathrm{~kg}$. Of these, 1,531 shaped tools and cores were recorded in detail (Curtis 2005) (Tables 1 and 2). Here, only frequencies and weights of formal tools, cores, and angular waste are presented. Of the formal tools and cores, unifacial scrapers (with high frequencies of endscrapers, sidescrapers, convergent scrapers, and thumbnail scrapers) dominate in frequency (36\% of the tools and cores), with single-platform cores (mostly pyramidal cores and single-platform blade cores) (16\%), and perforator/drill (9\%) tools also well represented (Tables 1 and 2 and Fig. 4).

At least 12 raw material types were identified in the excavated assemblages, with quartz by far the dominant raw material for both tools/cores (91\%) and angular waste (95\%). Obsidian, comprising 3\% of tools/cores and $4 \%$ of total chipped lithics, is the next most frequent. Of the remaining ten identified raw material types, only andesite and schist exceed $1 \%$ of the total. Chert and chalcedony combined make up less than $1 \%$ of the total, whether or not angular waste is included. The dominance of quartz is also seen clearly in other excavated first millennium BC sites in the greater Asmara area, including Sembel, Mai Chiot, and Weki Duba (Teka and Okubatsion 2008). Like the Mai Hutsa and Ona Gudo excavations, these other first millennium BC lithic assemblages contain very high frequencies of varied scraper tools, suggesting 


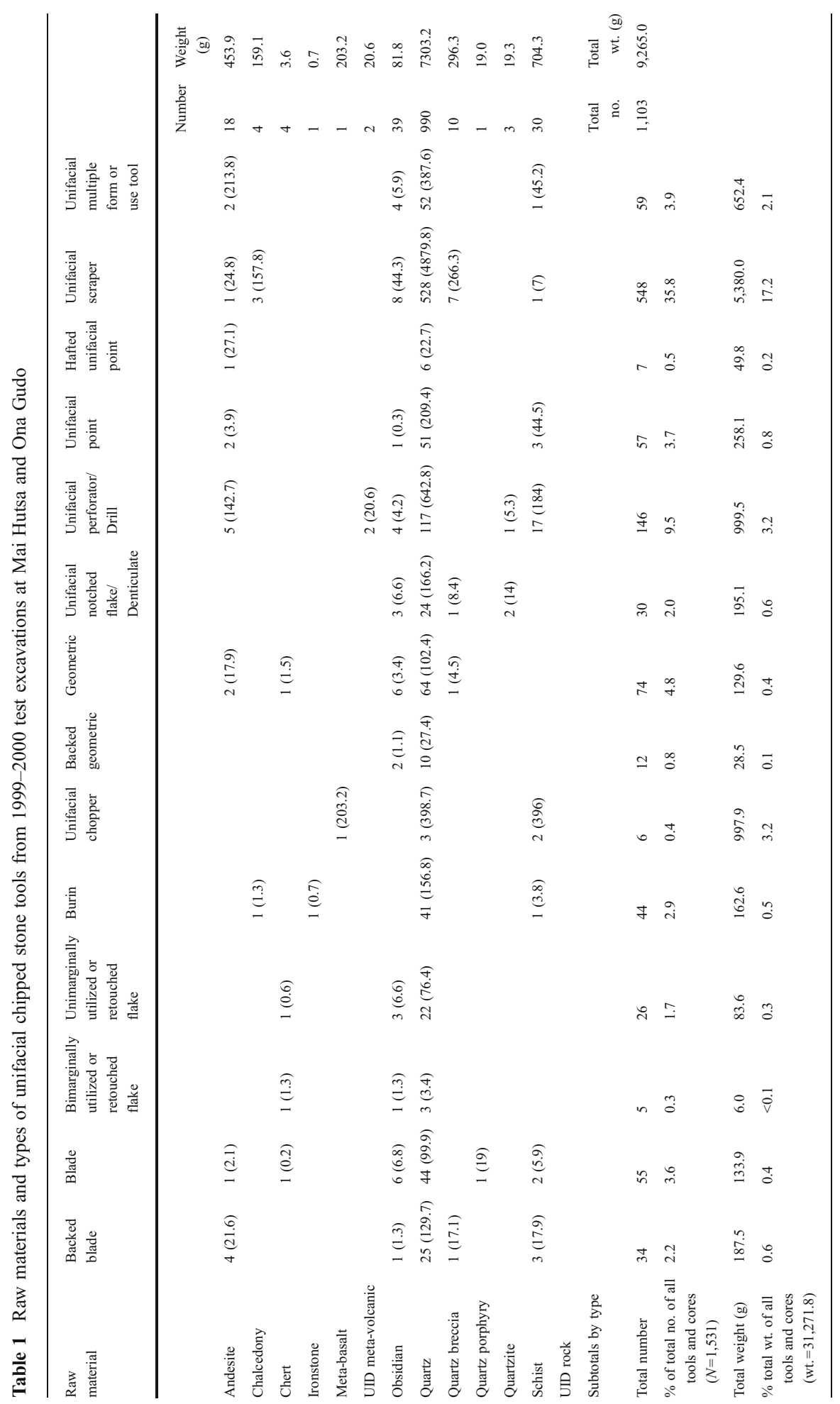




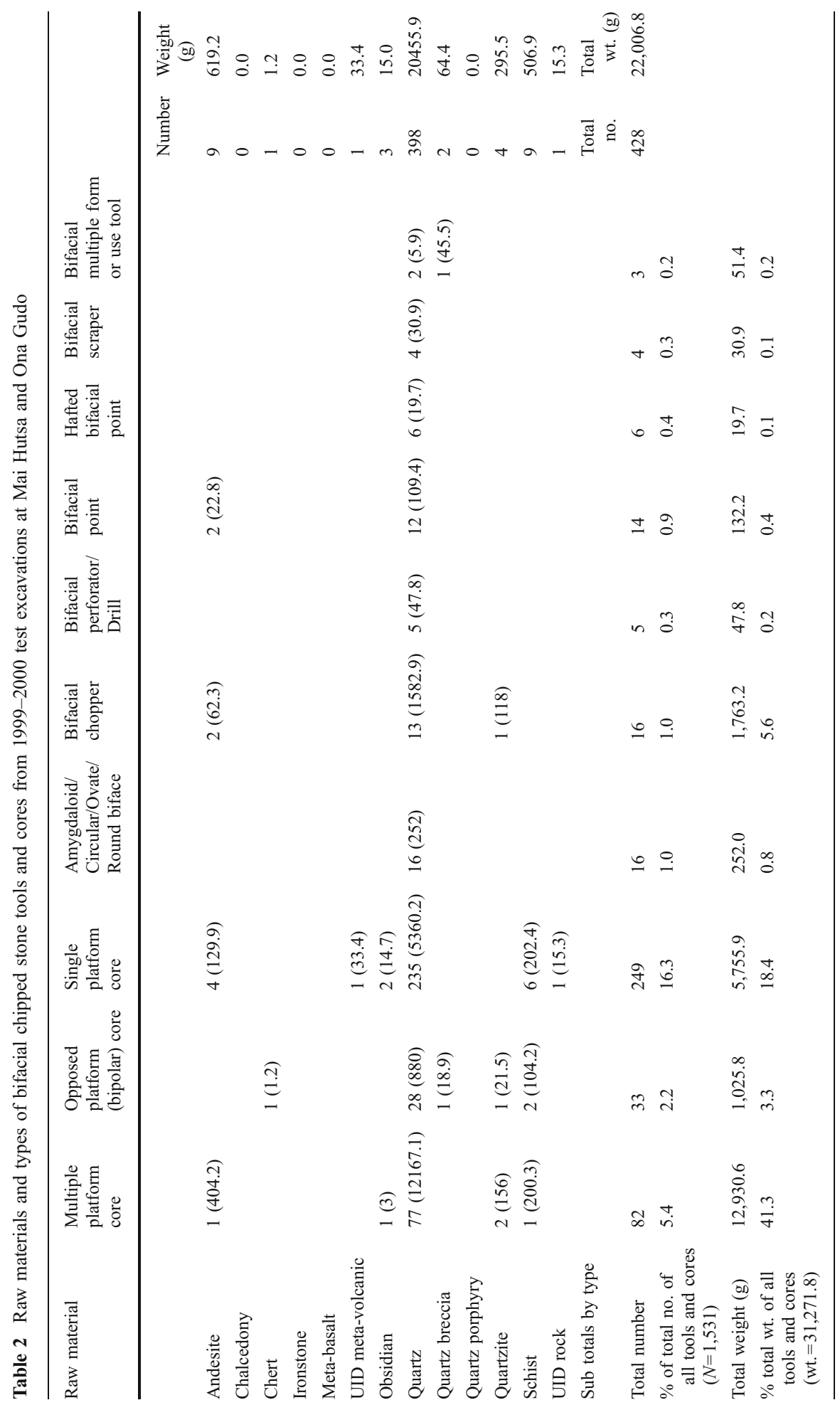




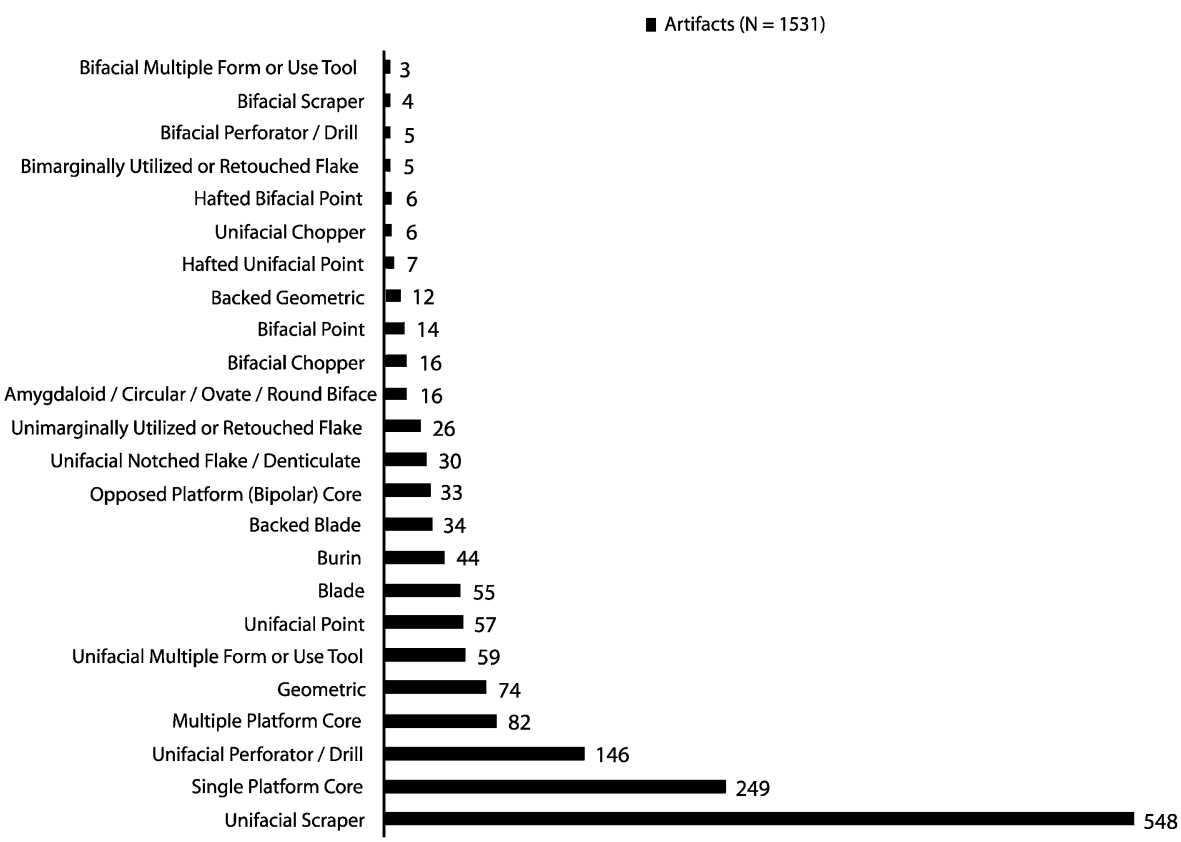

Fig. 4 Chipped stone tool and core types from Mai Hutsa and Ona Gudo

that quartz scrapers are the most characteristic chipped stone tool of the Ancient Ona culture (Figs. 4 and 5 and Table 1).

As in excavation assemblages, quartz also dominates site surface collections. The immediate availability of quartz may have driven this phenomenon. Ninety percent of Ancient Ona sites have substantial quartz veins or large quartz float areas within $50 \mathrm{~m}$, and in $88 \%$ of the 1,500 survey squares investigated, quartz raw material was readily observable in more than one location. With the exception of the bifacial blade form, quartz is represented in all chipped stone artifact categories in systematic surface collection material and in the excavated material from Mai Hutsa and Ona Gudo. Systematic surface collections in the greater Asmara survey area suggest that the frequency of obsidian tools and angular waste found in these excavations may be representative of the larger region, as obsidian makes up only $3 \%$ of all surfacecollected lithic artifacts. As in the excavated material, obsidian from systematic surface collections represented mostly small tools such as blades, geometric microliths, and small unimarginally utilized or retouched flake tools. Lithic data from other excavated contexts on the Asmara Plateau further illustrate this pattern, with obsidian comprising the second most frequent material (but low in overall percentage) and forming mostly small tool types. Only at Mai Hutsa do we see evidence for intensive obsidian use: $6 \%$ of the angular waste is obsidian, found mostly in a discrete feature suggesting a lithic workshop (Curtis 2005; Teka and Okubatsion 2008). As no obsidian source has been recorded on the Asmara Plateau, this material may have been at a premium. Obsidian's use mainly in small tool forms is, perhaps, testimony of its rarity and value. 
Scrapers and perforator/drills along with small blades (many of which are backed) and a range of geometric microliths (particularly triangles and crescents) characterize much of the first millennium BC lithic material from excavation and surface assemblages (Table 1 and Fig. 5). The high frequencies and variety of scraper and perforator/drill tools, often found in association with large milling stones and with substantial cattle and ovicaprine remains, suggest chipped stone-tool use geared toward a mixed agropastoral economy where the processing of domesticated animal hides may have been an important activity (Curtis 2005; Teka and Okubatsion 2008). This interpretation certainly fits well with available regional subsistence and settlement data for the Ancient Ona culture. How might it compare with material from first millennium BC sites in Tigray? Unfortunately, with the exception of Kidane Mehret, very little detailed analysis or reporting of chipped stone tools from first millennium BC contexts in Tigray appear in publication (but see D. W. Phillipson 2009, L. Phillipson 2000, 2009a, b). Thus, only very general contrasts and comparisons between regions can be made.

A range of scraper types, small backed blades, and highly standardized crescent forms characterize the "Pre-Aksumite" assemblage recovered at Kidane Mehret (L. Phillipson 2000, 2009a, b). Obsidian, chert, quartz, and siltstone are all present in the assemblage, with obsidian the favored raw material. Much of this assemblage is similar in form to Ancient Ona lithic material, with the exception that unlike the Asmara area, quartz makes up only a small proportion of the artifacts. In the GuloMakeda area, several "Pre-Aksumite" lithic workshop areas have been located at sites such as Grakasa, Adi Kesho I, Chekelte, and Mezber (D'Andrea et al. 2008a). Scrapers, backed microliths, and debitage have been reported, while raw materials included basalt, quartz, obsidian, and silicified siltstone, with obsidian and basalt particularly well represented.

In summary, we can certainly say that the Ancient Ona communities made heavy use of chipped stone tools, most of which were made from locally available raw material. The lithics are generally characterized by reliance upon quartz and a focus on several unifacial tool types, including a range of scraper forms, perforators/drills, small blades, and geometric microliths, particularly crescents and triangles. The challenge for future research will be to relate the Ancient Ona industry to earlier and later periods and to build comparative regional perspectives within the northern Horn. There are continuities with earlier lithic industries of the Later Stone Age in the wider Horn of Africa, particularly in the focus on microliths and the use of locally available material, but the intensive and extensive use of scrapers and perforators, perhaps related to the processing of domesticated cattle and goat/sheep hides, may represent a vital feature of Ancient Ona lithic production and use. There is some evidence that this is true of other "Pre-Aksumite" communities in the GuloMakeda and Aksum areas. Such observations should be explored in future research through renewed focus on the ways in which lithic tools were made and used in the agropastoral communities of the first millennium BC (see L. Phillipson 2000, 2009a, b).

\section{Ceramics}

Our understanding of Ancient Ona ceramics comes from analysis of test excavation material from stratified contexts at ten sites and from systematic surface collections 

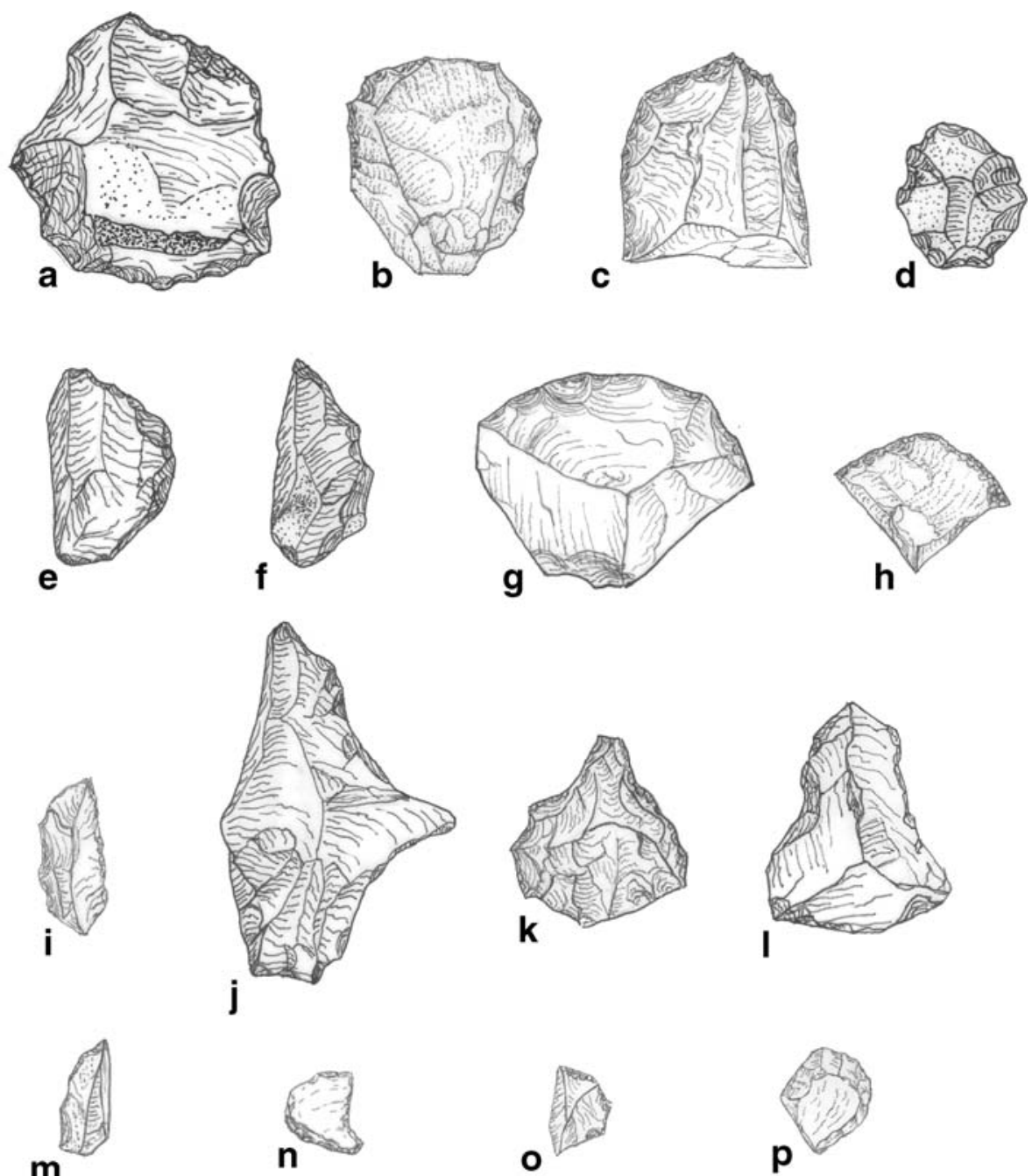

m
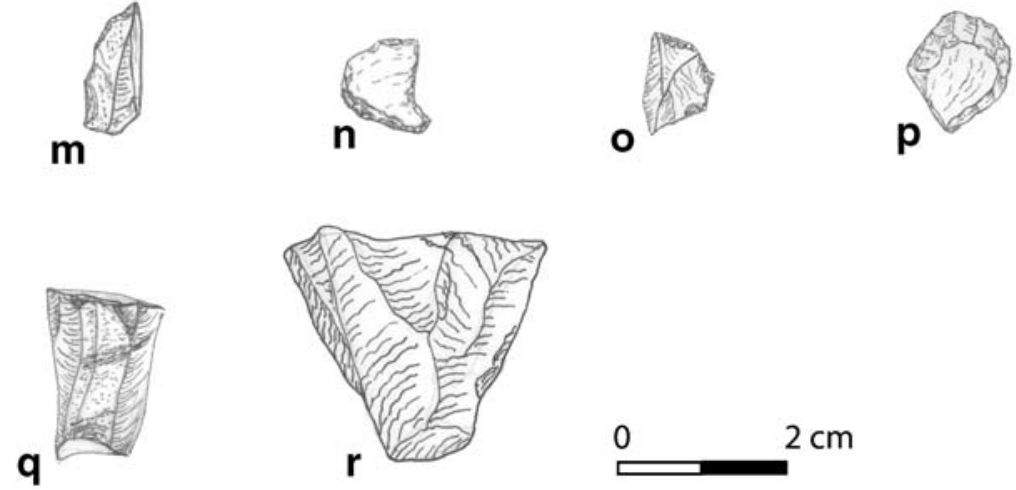

Fig. 5 Examples of chipped stone tools and cores from the Mai Hutsa test excavation: $a$ circular scraper; $b, c$ convergent scrapers; $d$ thumbnail scraper; $e, f$ side scrapers; $g, h$ end scrapers; $i$ unimarginally retouched flake tool; $j-l$ perforators; $m$ micro-blade; $n-p$ microliths; $q$ single platform blade core; $r$ pyramidal core 
conducted during the first phase of survey in the greater Asmara area. Of the excavated material, that from Sembel, Mai Hutsa, and Ona Gudo excavations has received the most comprehensive analysis (Curtis 2005; Mehari 2008; Schmidt et al. 2008b). The focus here is on the ceramic assemblages from tests at Mai Hutsa and Ona Gudo, which produced 15,566 sherds and a number of partial and whole vessels weighing a total of $162 \mathrm{~kg}$ (Table 3) and systematic surface collections from 80 sites that produced 34,597 Ancient Ona culture sherds weighing $143 \mathrm{~kg}$. Ancient Ona ceramics comprise $98 \%$ of all sherds recovered in the course of this survey, testimony to the dominant position of first millennium $\mathrm{BC}$ settlement on the archaeological landscape of the Asmara Plateau.

Ancient Ona ceramics characteristically represent finely produced handmade vessels of which the most common forms include: (1) pots with globular bodies, sloping shoulders, rounded bottoms, and everted, flaring rims, sometimes referred to as S-profile pots (e.g., Fattovich 2009); (2) piriform pots with slightly constricted necks and everted, slightly flaring and rounded rims; (3) miniature cups, often referred to as tina cups (Mehari 2008; Schmidt 2002; Schmidt et al. 2008b) that are 3-6 cm in diameter, with irregularly curved bodies, slightly rounded bottoms, bulbous necks, open mouths, and straight or slightly inverted rims; (4) shallow, thinwalled open bowls or deep dishes with rounded bottoms; (5) piriform jars with straight rims (similar to (2) above); (6) small to large jugs with moderately restricted necks and vertical lug handles on neck and shoulders; and (7) large globular storage or brewing pots with rounded bottoms and everted rounded rims (Fig. 6). Other ceramic forms documented from excavations of Ancient Ona sites include small, cylindrical vase-like vessels with straight or everted rims, braziers, a concave lid with handle, and a deep ladle (Curtis 2005; Schmidt et al. 2008b). Ancient Ona ceramics were handmade using at least three basic manufacturing techniques: coiling, pinching, and drawing. Evidence for coiling is found on various redware vessels, including a range of globular jars and pots. Evidence for scraping or wiping exteriors and interiors of red- and brownware vessels is common. Drawing clay by squeezing and pulling upwards seems also to have been utilized as there is ample evidence from various vessel forms, including tina cups, of finger-width indentations around vessel circumferences. The two most common handle types include looped lugs produced by a coiling technique and short flat horizontal lug handles.

Table 3 Ancient Ona ceramic types from Mai Hutsa and Ona Gudo test excavations

\begin{tabular}{lcc}
\hline Ceramic type & Number & Weight $(\mathrm{kg})$ \\
\hline Black-burnished ware with red slip & $2,159(13.9 \%)$ & $17.0(10.5 \%)$ \\
Black-burnished ware & $675(4.3 \%)$ & $4.1(2.5 \%)$ \\
Brownware & $701(4.5 \%)$ & $9.0(5.5 \%)$ \\
Coarse brownware & $450(2.9 \%)$ & $15.2(9.4 \%)$ \\
Coarse redware & $285(1.8 \%)$ & $10.3(6.4 \%)$ \\
Red-slipped ware & $3,481(22.4 \%)$ & $25.1(15.5 \%)$ \\
Redware & $7,015(45.1 \%)$ & $70.7(43.6 \%)$ \\
Unidentified and other ceramics & $800(5.1 \%)$ & $10.7(6.6 \%)$ \\
Totals & $15,566(100 \%)$ & $162.1(100 \%)$ \\
\hline
\end{tabular}



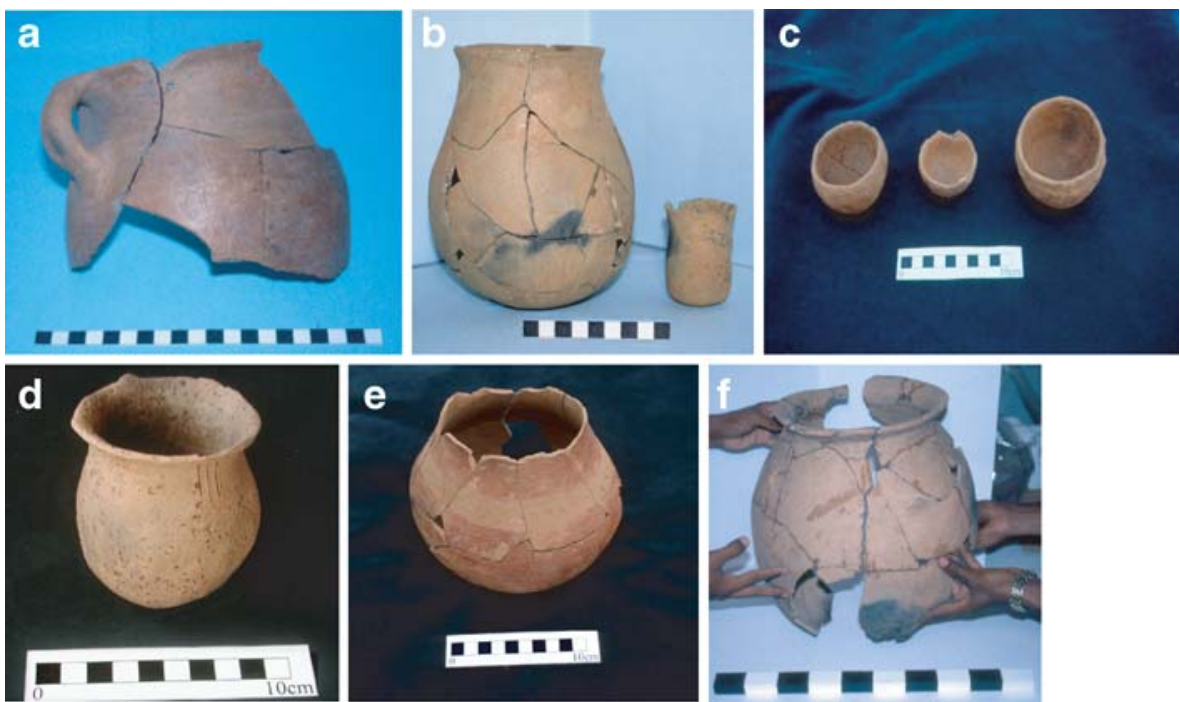

Fig. 6 Ancient Ona ceramic vessels from excavations in the greater Asmara area 1999-2003: a jug with lug handle from Ona Gudo (with 20-cm scale); b piriform pot and small vase or pot stand from Mai Hutsa (with 10-cm scale); c miniature cups from Sembel (with 10-cm scale); d small S-shaped pot with flaring rim from Weki Duba (with 10-cm scale); e globular pot with red slip and geometric designs from Sembel (with 10-cm scale); f large coarse brownware storage or brewing pot from Mai Hutsa (with 50-cm scale)

It has been recognized that early to mid-first millennium BC ceramic vessels often possess geometric motifs along shoulder and rim areas (Anfray 1990; Fattovich 1980, 1990, 1997, 2009; Schmidt and Curtis 2001). Overall, vessels from non-elite domestic contexts tend to have limited decoration, confined mostly to shoulder, neck, and rim exteriors. Decoration is characterized mostly by incised or combed bands, often in combinations of wavy, zigzag, or straight lines (Fig. 7). Punctates,
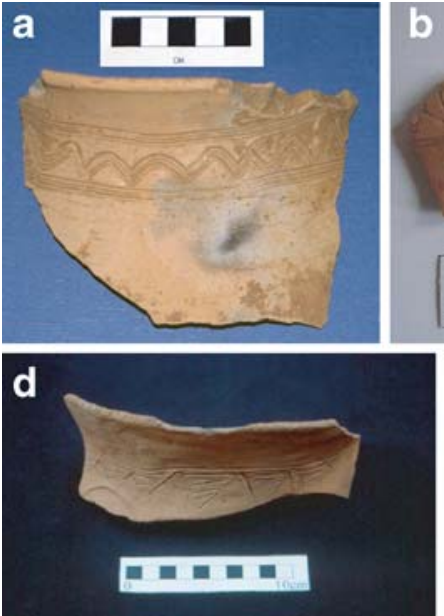
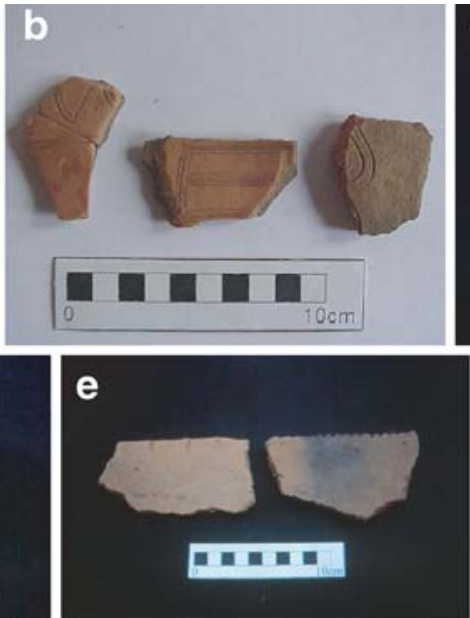
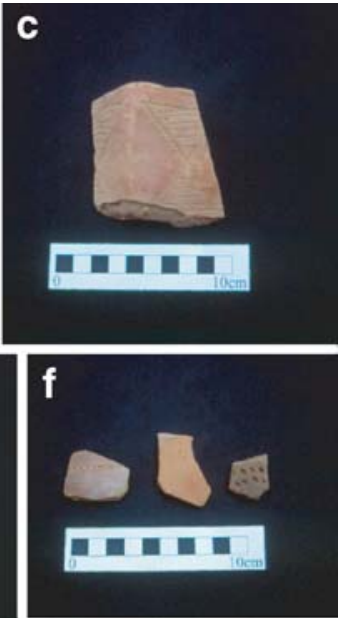

Fig. 7 Common Ancient Ona ceramic decorative motifs: a wavy lines bordered by dual parallel lines; b wavy lines; c, $\mathbf{d}$ hatched-filled rows of triangles; e dash punctates on rim; $\mathbf{f}$ row of punctates 
raised bosses, and a limited range of applied strips or appliqué also are found in shoulder, neck, and rim exteriors. We may recognize three distinct decorative pattern combinations on early to mid-first millennium BC ceramic vessels that appear frequently in assemblages across the landscape of the northern Horn, from the Asmara Plateau to Tigray. One of the most commonly found patterns on a range of vessel types are rows or bands of alternating incised triangles containing hatched or cross-hatched lines (Fig. 7c, d; D’Andrea et al. 2008a: 166, Fig. 8; Fattovich 1980, tavv. vii, viii, xxi, xxiii, xxxiii, xxxiv, xxxvi; Mehari 2008: 168, Fig. 7.5). Two rows of triangles with hatched or cross-hatched incisions are often separated by parallel incised lines (e.g., Schmidt et al. 2008b: 144, Fig. 6.45). A second common pattern on shoulders and necks comprises linear parallel or zigzag combed or incised bands separated by discontinuous horizontal tick lines or punctates. A third motif frequently encountered is a row of wavy combed or incised lines set between or above parallel incised lines, or the converse, a horizontal central incised band with wavy borders (Fig. 7; Phillips 2000: 207, Fig. 266c, 310, Fig. 270a). This last motif is common on the shoulders of small- to medium-sized globular pots with rounded bottoms and slightly everted and rounded rims, often displaying an S-profile (e.g., de Contenson 1963: pls. iii b3, liv. B). Piriform pots, similar in general form to the Sprofile ones and also bearing this decorative motif, are found in both Tigray and the greater Asmara area.

Fabric and surface treatment differentiate seven distinct general ware types: redware, red-slipped ware, black-burnished ware, black-burnished ware with red slip, brownware, coarse brownware, and coarse redware. Excavations at Ancient Ona sites, including Mai Hutsa and Ona Gudo, suggest that the principal types occur coevally throughout the early to mid-first millennium BC. While there are changes in type frequencies by excavation level and evidence of temporary abandonment of houses at Sembel and, perhaps, Ona Gudo and Mai Hutsa, there is general continuity of types throughout the excavated deposits, suggesting that a single locally produced ceramic tradition is represented (Figs. 8 and 9).

Redware often possesses a red finish on the exterior, but the interior is variable, ranging from red, black, and sometimes burnished black. Red-slipped ware has a fine temper, thin walls, and a thin red slip likely applied before firing. Redware and red-slipped ware pastes are often friable, red to orange in color, tempered with quartz, laterite, mica, and feldspar inclusions less than $3 \mathrm{~mm}$ in dimension. Perhaps the most common vessel forms of these wares in Ancient Ona site assemblages are S-profile and piriform pots (Fig. 6b, d); these forms also are found widely in burial and domestic contexts at first millennium BC sites to the south (Anfray 1963: pls. cxxxvi e, f; cxxxvii b; Duncanson 1947: pl. viii; de Contenson 1963: pls. lv a3, a4, lvi a, b; Phillips 2000: 306 Figs. 266b, 266e). Another notable redware form of the greater Asmara area ceramic assemblages that has parallels, but not exact duplication, in other areas of the northern Horn is that of the tina cups (Fig. 6c). Such cups occur in dense quantities in Ancient Ona contexts such as Sembel (Curtis 2005; Mehari 2008; Schmidt 2002; Schmidt and Curtis 2001; Schmidt et al. 2008b). While small cups are documented from other first millennium BC contexts in the northern Horn (e.g., Fattovich 1980; de Contenson 1963: pl. lv, b1-3), the frequency and unusually small diameters of the Ancient Ona examples point to a particularly characteristic feature of material culture in the greater Asmara area. 


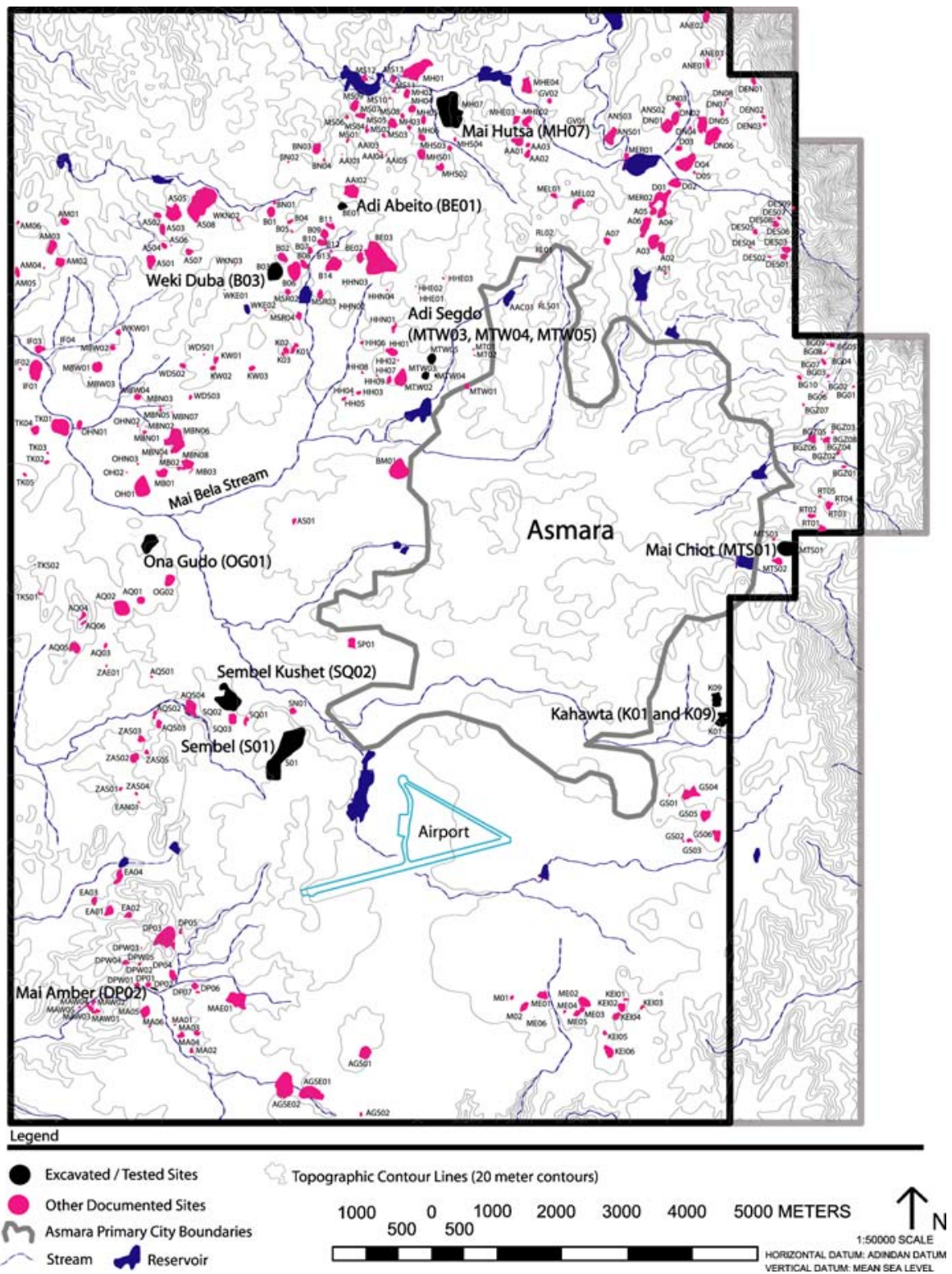

Fig. 8 Excavated sites around Asmara. For in-print edition color version of this map, see P.R. Schmidt, this volume

Brownware possesses a medium coarse paste and temper generally similar to those of redware, but with a distinct color that might indicate a different firing process. As with redware, scraping or wiping of interior and exterior surfaces is common.

Black-burnished ware possesses a fine and hard paste, often with a high sheen on both exterior and interior. Mehari (2008) has argued that it is technologically similar to red-slipped ware and has subsumed it as a variant. Here, however, the black- 


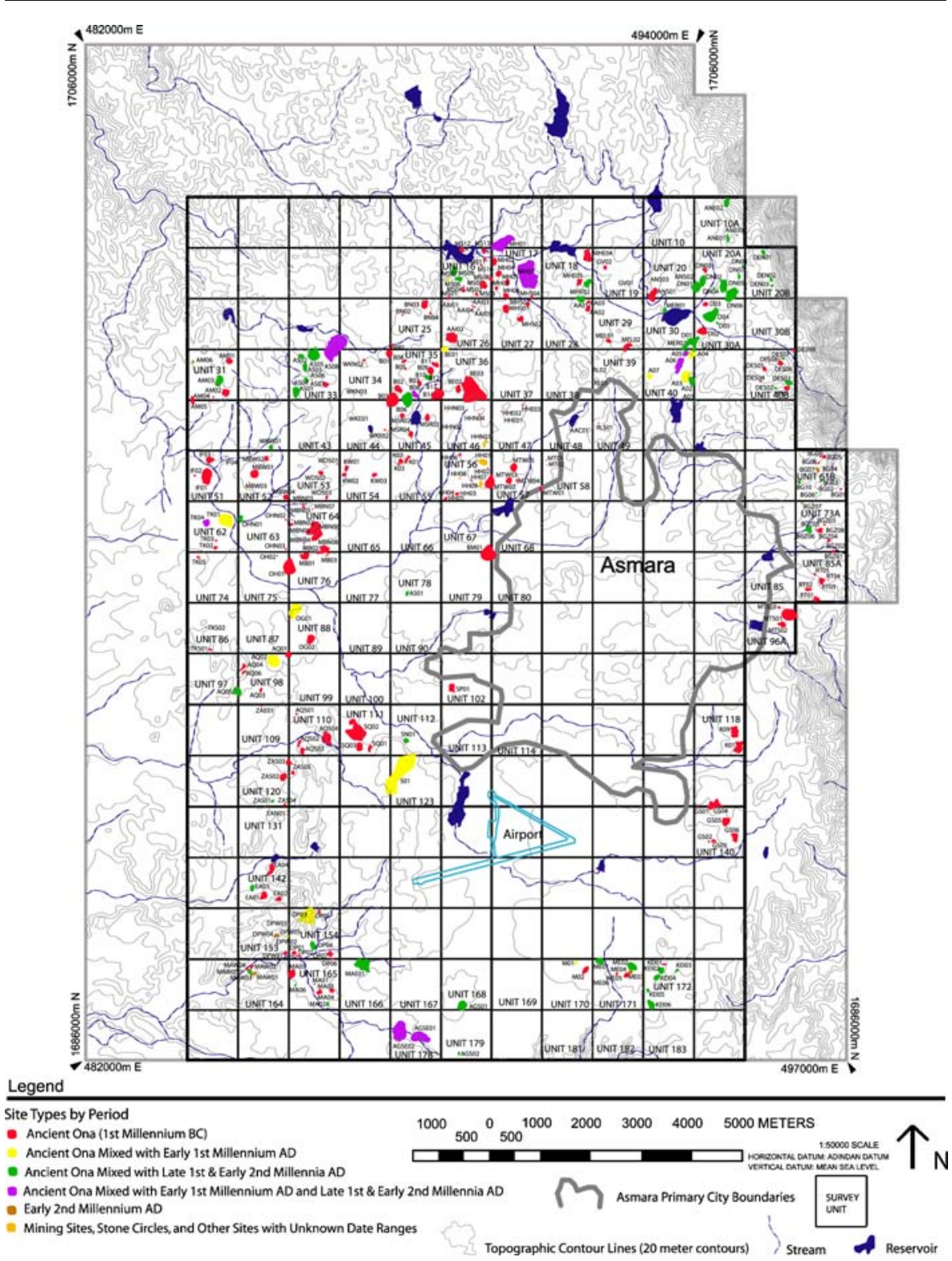

Fig. 9 Sites of different cultural periods, color coded as per legend. Each survey grid square represents $1 \mathrm{~km}^{2}$. For in-print edition color version of this map, see P.R. Schmidt, this volume

burnished ware with red slip is treated separately, as it appears in $18 \%$ of systematic surface collections and makes up $14 \%$ of the excavated sherds from Mai Hutsa and Ona Gudo (Table 3). This material is similar to what has been referred to as blacktopped redware, one of the most widespread categories in the ceramics of the northern Horn during the first millennium BC and well represented in both elite and domestic contexts in a diverse array of sites including Yeha (Fattovich 1980, 2009), 
Kidane Mehret (Phillips 2000, 2004), and Sobea (Leclant and Miquel 1959) in Tigray and Matara in Akele Guzay (Anfray 1966).

Coarse brown- and coarse redwares are very likely subtypes of the same general ware. The differences in color probably relate to firing conditions. They are distinguished from non-coarse wares by thick vessel walls, greater frequency and larger size of tempering, and a rough finish that often exhibits evidence of brushing. Exfoliation of walls and evidence of burning and sooting on exteriors regularly occur in these coarse-ware ceramics. Common coarse-ware vessel forms include large globular storage pots, open bowls, and possible brewing vessels (Fig. 6f: Schmidt 2002; Schmidt and Curtis 2001). Many coarse-ware vessels appear to have exceeded $50 \mathrm{~cm}$ in height and $18 \mathrm{~cm}$ in mouth diameter; most were likely undecorated, except for occasional vertical incisions near the rim and shoulders and above small horizontal lugs. Generally similar forms of large storage vessels are present in black-topped redware from "Pre-Aksumite" contexts at Kidane Mehret (see Phillips 2000: 305-310, Figs. 268-269).

While the combinations of paste, surface, and decorative treatments in the first millennium BC ceramics of the greater Asmara area create distinct Ancient Ona signatures, it is clear that a number of important characteristics are shared with ceramics from "Pre-Aksumite" sites across the wider northern Horn. Indeed, it is possible to view the Ancient Ona ceramic tradition as part of a broader pan-regional material culture tradition drawn upon by various communities inhabiting the northern highlands at this time. The relatively limited observations presented above are testimony to the general lack of systematic ceramic research; only one panregional comparative study of "Pre-Aksumsite" pottery has been conducted (Fattovich 1980). Although some advances in typological analyses have been made, we lack studies of ceramic technology, use alteration, sourcing, etc. The situation is exacerbated by the current political and logistical difficulties of working between collections in Ethiopia and Eritrea. Attempts such as that presented here must be regarded as initial and preliminary steps toward building an understanding of ceramic traditions and their potential role for identifying local, regional, and macroregional signatures of identity and adaptation in physical and social environments of the first millennium BC.

\section{Concluding Thoughts}

The last 15 years have seen the resumption of archaeological research in the northern Horn after almost two decades. Characteristic of this more recent research has been an explicit concern for building localized, regional, and pan-regional perspectives of ancient settlement, material culture, and subsistence through systematic regional survey and excavation of domestic contexts (e.g., Bard et al. 1997; Curtis 2005, 2008; D’Andrea et al. 2008a; Fattovich et al. 2000; Finneran 2007; D. W. Phillipson 2000; Schmidt et al. 2008a; Schmidt and Curtis 2001). While earlier fieldwork tended to focus on monumental and specialized ritual contexts, more recent research has broadened our perspectives, providing new insights concerning the timing and distribution of first millennium BC agropastoral communities. We are now beginning to perceive defining qualities of the archaeologies of particular regions even as we 
observe larger patterns in settlement, subsistence, and material culture traditions uniting regions across the northern Horn. The continuation of this nascent but vital research trend will be reliant on the building of multiscalar perspectives about the past. Fortunately, we are in a good position to do this, given the diverse and rich range of data types available in the archaeology and the environmental and cultural histories of the northern Horn of Africa. Early written texts, oral traditions, a deep and varied archaeological record including open air and rockshelter sites, a diversity of physiographic and altitudinal zones in short horizontal distances, a landscape well suited for pedestrian survey and the potential for dynamic landscape archaeology, and extant and potential environmental data from Rift Valley lakes and sediment cores make the northern Horn ideal for multiscalar analysis.

If we are to replace vague terms such as "Pre-Aksumite" with more contextually bound and informed culture-historical terminology, we must acknowledge in our research design and interpretations that ancient cultures were multivariate rather than univariate phenomena. We must guard against conflating the terms "culture group" and "culture period" (see D. W. Phillipson 2009), and we must consider the dynamic and situational nature of ethnicity, recognizing that the relationship between variation in material culture and the expression of cultural or ethnic differences is complex. The archaeology of the Ancient Ona culture of Eritrea forces us to consider such issues directly. Here, we have archaeological evidence suggesting significant connections with ancient communities in Akele Guzay and Tigray more than $100 \mathrm{~km}$ to the south. We can see a range of similar cultural expressions embodied in artifact, settlement, and subsistence traditions. Yet there are also vital differences. Exploring such similarities and differences in relation to environmental and local culture histories will be crucial for exploring larger questions. Why did a fully agropastoral tradition appear in the Greater Asmara area in the early first millennium BC seemingly with such rapidity? Why were communities on the Asmara Plateau abandoned in the fourth century BC? Why do signs of elite identity, often exhibited with symbols and forms derived from South Arabian antecedents, appear in a limited number of site areas in the northern Horn, but are largely missing in the archaeology of the Greater Asmara area and other regions?

On the Asmara Plateau, we can see densely settled communities living in a range of settlement types including towns but showing few signs of social differentiation and suggesting a focus on the commons. Such situations are not restricted to the greater Asmara area, as evidenced by the D Site at Kidane Mehret, the Gulo-Makeda landscape, and even the Aksum-Yeha corridor. How were specialized ceremonial and presumably elite centers such as Yeha linked to the surrounding region, a landscape largely devoid of similar overtly monumental and conspicuous expressions of prestige? Such questions are fundamentally tied to our ability to integrate local, regional, and macro-regional perspectives in the northern Horn. Future research should focus on investigating evidence of social relations within and between local communities and consider the possibility that cycles of change between egalitarian and hierarchical social relations may have been operating in the northern Horn during the first millennium BC. We need to find ways to identify individual, sectional, and communal interests and sequences of change in the archaeological record rather than merely focus on identifying synchronic social types and stages of complexity (see McIntosh 1999; Chapman 2007), and we need to 
recognize that ancient societal structures of the northern Horn may have moved along a continuum between heterarchy and hierarchy tied to modulations within particular historical contexts and transforming cultural norms and values. Crucial will be our ability to identify archaeologically the social processes embodying elements of both egalitarian and hierarchical organization, such as cooperation and competition, collective power strategies, community and regional systems of control, and aspects of household and localized autonomy (Crumley 1995; Souvatzi 2007: 53; Wynne-Jones and Kohring 2007: 6). Many of the insights presented in this special issue of the African Archaeological Review suggest that we have now begun such explorations in the archaeology of the northern Horn of Africa. Let us continue this endeavor.

Acknowledgments Thanks to David Phillipson and Peter Schmidt for helping improve earlier drafts of this paper and for organizing the session "Pre-Aksumite Ethiopia and Eritrea" at the 19th SAfA Biennial Meeting in Frankfurt/Main, Germany. Thank you to the University of California, Santa Barbara and the Society of Africanist Archaeologists for conference travel grant funding in 2008. Funding and/or logistical support for research reported here was made possible by the US Fulbright Program, the US Embassy in Eritrea, the National Museum of Eritrea, the University of Asmara, the Central Florida Chapter of the Explorers Club, and the University of Florida Department of Anthropology and Center for African Studies. Field and laboratory work in Eritrea was made possible with the support of Yosief Libseqal, Rezene Russom, and staff of the National Museum of Eritrea, and the former faculty and students of the University of Asmara archaeology field schools program. Thanks also to Mary Prendergast for French language abstract translation and to Lalemba Tsehaie for lithic artifact illustrations. Finally, thanks go to the three anonymous reviewers and to Adria LaViolette for her editorial suggestions and encouragement.

Open Access This article is distributed under the terms of the Creative Commons Attribution Noncommercial License which permits any noncommercial use, distribution, and reproduction in any medium, provided the original author(s) and source are credited.

\section{References}

Anfray, F. (1963). Une campagne de fouilles à Yeha (Février-Mars 1960). Annales d'Éthiopie, 5, 171-192.

Anfray, F. (1966). La poterie de Matara. Rassegna di Studi Etiopici, 23, 5-19.

Anfray, F. (1968). Aspects de l'archéologie éthiopienne. Journal of African History, 9, 345-366.

Anfray, F. (1972a). Fouilles de Yeha. Annales d'Éthiopie, 9, 45-56.

Anfray, F. (1972b). Les fouilles de Yeha, Mai-Juin 1972. Documents pour servir à l'histoire des civilisations éthiopiennes, 3, 57-64.

Anfray, F. (1973). Les fouilles de Yeha, Mai-Juin 1973. Documents pour servir à l'histoire des civilisations éthiopiennes, 4, 35-38.

Anfray, F. (1990). Les anciens éthiopiens. Paris: Colin.

Anfray, F. (1997). Yeha, les ruines de Grat Be'al Gebri: Recherches archéologiques. Rassegna di Studi Etiopici, 39, 5-23.

Bard, K. A., Fattovich, R., Manzo, A., \& Perlingieri, C. (1997). Archaeological investigations at Bieta Giyorgis, Aksum, Ethiopia. Journal of Field Archaeology, 24, 387-404.

Boardman, S. (1999). The agricultural foundation of the Aksumite Empire, Ethiopia: An interim report. In M. van der Veen (Ed.), The exploitation of plant resources in ancient Africa (pp. 137-148). New York: Kluwer.

Boardman, S. (2000). Contributions on archaeobotany. In D. W. Phillipson (Ed.), Archaeology at Aksum, Ethiopia, 1973-7 (pp. 268-270, 363-368, 412-414). London: British Institute in Eastern Africa and Society of Antiquaries.

Boardman, S., \& Phillipson, D. W. (2000). Archaeobotany. In D. W. Phillipson (Ed.), Archaeology at Aksum, Ethiopia, 1973-7 (pp. 468-470). London: British Institute in Eastern Africa and Society of Antiquaries. 
Cain, R. C. (2000). Contributions on archaeozoology. In D. W. Phillipson (Ed.), Archaeology at Aksum, Ethiopia, 1993-7 (pp. 218, 369-372, 414-417, 510-511). London: British Institute in Eastern Africa and Society of Antiquaries.

Chapman, R. (2007). Evolution, complexity and the state. In S. Kohring \& S. Wynne-Jones (Eds.), Socialising Complexity: structure, interaction and power in archaeological discourse (pp. 13-28). Oxford: Oxbow.

Crumley, C. L. (1995). Heterarchy and the analysis of complex societies. In R. M. Ehrenreich, C. L. Crumley \& J. E. Levy (Eds.), Heterarchy and the analysis of complex societies (pp. 1-5). Arlington: American Anthropological Association (Archaeological Papers, no. 6).

Curtis, M. C. (2004). Ancient interaction across the southern Red Sea: New suggestions for cultural exchange and complex societies during the first millennium BC. In P. Lunde \& A. Porter (Eds.), Trade and travel in the Red Sea region (pp. 57-70). Oxford: Archaeopress.

Curtis, M. C. (2005). Archaeological investigations in the Greater Asmara Area: A regional approach in the central highlands of Eritrea. PhD dissertation, University of Florida.

Curtis, M. C. (2008). New perspectives for examining change and complexity in the northern Horn of Africa during the first millennium BCE. In P. R. Schmidt, M. C. Curtis \& Z. Teka (Eds.), The archaeology of ancient Eritrea (pp. 329-348). Trenton: Red Sea Press.

Curtis, M. C., \& Habtemichael, D. (2008). Matara, Keskese and the 'Classical Period' archaeology of the Akkele Guzay highlands: A brief overview. In P. R. Schmidt, M. C. Curtis \& Z. Teka (Eds.), The archaeology of ancient Eritrea (pp. 311-327). Trenton: Red Sea Press.

Curtis, M. C., \& Schmidt, P. R. (2008). Landscape, people, and places on the ancient Asmara plateau. In P. R. Schmidt, M. C. Curtis \& Z. Teka (Eds.), The archaeology of ancient Eritrea (pp. 64-108). Trenton: Red Sea Press.

D’Andrea, A. C., Manzo, A., Harrower, M. J., \& Hawkins, A. (2008a). The Pre-Aksumite and Aksumite settlement of northeast Tigrai, Ethiopia. Journal of Field Archaeology, 33, 151-176.

D’Andrea, C. A., Schmidt, P. R., \& Curtis, M. C. (2008b). Paleoethnobotanical analysis and agricultural economy at early first millennium BCE sites around Asmara. In P. R. Schmidt, M. C. Curtis \& Z. Teka (Eds.), The archaeology of ancient Eritrea (pp. 207-216). Trenton: Red Sea Press.

de Contenson, H. (1963). Les fouilles à Haoulti en 1959-Rapport préliminaire. Annales d'Éthiopie, 5, 41-86.

de Contenson, H. (1981). Pre-Aksumite culture. In G. Mokhtar (Ed.), UNESCO general history of Africa, vol. 2 (pp. 341-361). London: Heinemann.

Duncanson, D. J. (1947). Girmaten: A new archaeological site in Eritrea. Antiquity, 21, 158-163.

Fattovich, R. (1972a). Sondaggi stratigrafici, Yeha 1971. Annales d'Éthiopie, 9, 65-86.

Fattovich, R. (1972b). Yeha 1972, sondaggi stratigrafici. Documents pour servir à l'histoire des civilisations éthiopiennes, 3, 65-75.

Fattovich, R. (1980). Materiali per lo studio della ceramica pre-Aksumita Etiopica. Naples: Istituto Universitario Orientale.

Fattovich, R. (1990). Remarks on the Pre-Aksumite period in northern Ethiopia. Journal of Ethiopian Studies, 23, 1-33.

Fattovich, R. (1997). The Near East and Eastern Africa: Their interaction. In J. O. Vogel (Ed.), Encyclopedia of Precolonial Africa: Archaeology, history, languages, cultures and environments (pp. 479-484). Walnut Creek: AltaMira.

Fattovich, R. (2009). Reconsidering Yeha, c. 800-400 BC. African Archaeological Review, 26, 275-290.

Fattovich, R., Bard, K. A., Petrassi, L., \& Pisano, V. (2000). The Aksum Archaeological Area: A preliminary assessment. Naples: Istituto Universitario Orientale.

Finneran, N. (2007). The archaeology of Ethiopia. London: Routledge.

Leclant, J., \& Miquel, A. (1959). Reconnaissance dans l'Agamé: Goulo-Makéda et Sabéa. Annales d'Éthiopie, 3, 107-114.

Libseqal, Y. (2005). Rescue excavations at Mai Temenay. In W. Raunig \& S. Wenig (Eds.), Afrikas Horn (p. 427). Wiesbaden: Harrassowitz.

Lyons, D. E. (2007). Building power in rural hinterlands: An ethnoarchaeological study of vernacular architecture in Tigrai, Ethiopia. Journal of Archaeological Method and Theory, 14, 153-178.

Manzo, A. (2009). Capra nubiana in berbere sauce?-A constructionist approach to pre-Aksumite art. African Archaeological Review, 26.

McIntosh, S. K. (1999). Pathways to complexity: An African perspective. In S. K. McIntosh (Ed.), Beyond Chiefdoms: Pathways to complexity in Africa (pp. 1-30). Cambridge: Cambridge University Press.

Mehari, A. (2008). Ceramic analysis of Sembel site: Cultural stratigraphy. In P. R. Schmidt, M. C. Curtis \& Z. Teka (Eds.), The archaeology of ancient Eritrea (pp. 163-177). Trenton: Red Sea Press. 
Michels, J. W. (1979). Axumite archaeology: An introductory essay. In Y. Kobishchanov (Ed.), Axum (pp. 1-24). University Park: Pennsylvania State University Press.

Michels, J. W. (1994). Regional political organisation in the Axum-Yeha area during the Pre-Aksumite and Aksumite eras. Etudes ethiopiennes, 1, 61-80.

Michels, J. W. (2005). Changing settlement patterns in the Aksum-Yeha region of Ethiopia, 700B-AD 850. Oxford: Archaeopress.

Phillips, J. S. (2000). Pottery and clay objects [from D site at Kidane Mehret]. In D. W. Phillipson (Ed.), Archaeology at Aksum, Ethiopia, 1993-97 (pp. 303-337). London: British Institute in Eastern.

Phillips, J. S. (2004). Pre-Aksumite Aksum and its neighbours. In P. Lunde \& A. Porter (Eds.), Trade and travel in the Red Sea region (pp. 79-85). Oxford: Archaeopress.

Phillipson, D. W. (2000). Archaeology at Aksum, Ethiopia, 1993-97. London: British Institute in Eastern Africa and Society of Antiquaries.

Phillipson, L. (2000). Lithics [from D site at Kidane Mehret]. In D. W. Phillipson (Ed.), Archaeology at Aksum, Ethiopia, 1993-97 (pp. 352-363). London: British Institute in Eastern Africa and Society of Antiquaries.

Phillipson, D. W. (2009). The first millennium BC in the highlands of northern Ethiopia and south-central Eritrea: A re-assessment of cultural and political development. African Archaeological Review, 26, 257-274. doi:10.1007/s10437-009-9064-2.

Phillipson, L. (2009a). Lithic artefacts as a source of cultural, social and economic information: The evidence from Aksum, Ethiopia. African Archaeological Review, 26, 45-54.

Phillipson, L. (2009b). Using stone tools: The evidence from Aksum, Ethiopia. Oxford: Archaeopress.

Robin, C. \& de Maigret, A. (1998). Le grand temple de Yéha (Tigray, Éthiopie) après la première campagne de fouilles de la mission française. Comptes-rendus des séances de l'Académie des Inscriptions et Belles-Lettres, 1998, 737-798.

Schmidt, P. R. (2002). The 'Ona' culture of greater Asmara: Archaeology's liberation of Eritrea's ancient history from colonial paradigms. Journal of Eritrean Studies, 1, 29-58.

Schmidt, P. R. (2009). How variations in Eritrea shape the archaeology of the northern Horn during the first millennium BC. African Archaeological Review, 26, 305-325.

Schmidt, P. R. \& Curtis, M. C. (2001). Urban precursors in the Horn: Early first millennium BC communities in Eritrea. Antiquity, 75, 849-859.

Schmidt, P. R., Curtis, M. C., \& Teka, Z. (Eds). (2008a). The archaeology of ancient Eritrea. Trenton: Red Sea Press.

Schmidt, P. R., Curtis, M. C., \& Teka, Z. (2008b). The Ancient Ona communities of the first millennium BC: Urban precursors and independent development on the Asmara plateau. In P. R. Schmidt, M. C. Curtis \& Z. Teka (Eds.), The archaeology of ancient Eritrea (pp. 109-177). Trenton: Red Sea Press.

Shoshani, J., Ghebregiorgis, M., \& Schmidt, P. R. (2008). Interpretations of faunal remains from archaeological sites on the Asmara plateau of Eritrea. In P. R. Schmidt, M. C. Curtis \& Z. Teka (Eds.), The Archaeology of Ancient Eritrea (pp. 217-233). Trenton: Red Sea Press.

Souvatzi, S. (2007). Social complexity is not the same as hierarchy. In S. Kohring \& S. Wynne-Jones (Eds.), Socialising complexity: Structure, interaction and power in archaeological discourse (pp. 3759). Oxford: Oxbow.

Teka, Z., \& Okubatsion, D. (2008). Lithic artifacts from archaeological sites in the Greater Asmara area. In P. R. Schmidt, M. C. Curtis \& Z. Teka (Eds.), The archaeology of ancient Eritrea (pp. 189-205). Trenton: Red Sea Press.

Wynne-Jones, S. \& Kohring, S. (2007). Socialising complexity. In S. Kohring \& S. Wynne-Jones (Eds.), Socialising complexity: Structure, interaction and power in archaeological discourse (pp. 2-12). Oxford: Oxbow. 